Mineralogical Journal, Vol. 2, No. 1, pp. 1-18, Dec., 1956

\title{
THE CRYSTAL STRUCTURE OF BORAX*
}

\author{
NOBUO MORIMOTO \\ Mineralogical Institute, University of Tokyo
}

\begin{abstract}
The crystal structure of borax, $\mathrm{Na}_{2} \mathrm{~B}_{4} \mathrm{O}_{7} \cdot 10 \mathrm{H}_{2} \mathrm{O}$, has been worked out by means of the sign relationships of structure factors and by the triple Fourier series method. The unit cell has the dimensions of $a_{0}=11.858 \AA, b_{0}=10.674 \AA$, $c_{0}=12.197 \AA$ and $\beta=106^{\circ} 41^{\prime}$, and the space group is $C_{2 h}^{6}$. There are four chemical units of composition, $\mathrm{Na}_{2} \mathrm{~B}_{4} \mathrm{O}_{7} \cdot 10 \mathrm{H}_{2} \mathrm{O}$ in the unit cell. The coordinates of atoms were refined first by double Fourier series and the final triple. Fourier series were carried out with 1763 terms. The standard deviations of coordinates finally obtained are $0.004 \AA$ for sodium atoms, $0.02 \AA$ for boron atoms and $0.02 \AA$ for oxygen atoms. Hydrogen atoms have been located from the consideration on the electrostatic valencies directed to the oxygen atoms and the interatomic distances between oxygen atoms.

The structure of borax is composed of chains of regular octahedra formed by water molecules around $\mathrm{Na}$, running parallel to the $\mathrm{c}$-axis. These chains build up a sheet holding isolated groups of $\mathrm{B}_{4} \mathrm{O}_{5}(\mathrm{OH})_{4}$ in between them through hydrogen bonds. These sheets are parallel to $(100)$ and held together mainly by hydrogen bonds. The structure formula of borax may best be represented with the expression $\mathrm{B}_{4} \mathrm{O}_{5}(\mathrm{OH})_{4} \cdot \mathrm{Na}_{2} 8 \mathrm{H}_{2} \mathrm{O}$.
\end{abstract}

\section{Introduction}

There have remained many problems unsolved concerning the crystal structures of borate minerals and their mutual relations, among which borax, $\mathrm{Na}_{2} \mathrm{~B}_{4} \mathrm{O}_{7} \cdot 10 \mathrm{H}_{2} \mathrm{O}$, is of most importance because of its practical use. In the present study, the crystal structure of borax was determined as part of a programme of investigation of the borate minerals at this Mineralogical Institute. The structure of this mineral is of special interest because of the possibility of finding the structural units of boron, oxygen and hydrogen atoms which or part of which might give clues to solve the structure of

* Read at the Amual Meeting of the Mineralogical Society of Japan held in Kyoto on Oet. 23, 1955. 
other borate minerals and because of the role played in the structure by the hydrogen atoms.

Since no assumption was made about the location of hydrogen atoms in advance, and they are omitted in calculating the structure factors, the term "oxygen atom" throughout this paper will be used comprehensively to include $\mathrm{O}^{2-}, \mathrm{OH}^{-}$and $\mathrm{H}_{2} \mathrm{O}$ groups, without distinguishing between them, except where context makes distinction obvious.

Only few X-ray studies on borax have so far been reported. W. Minder ${ }^{8)}$ gave, in 1935, the lattice constants and space group of borax with other kindred minerals such as kernite $\left(\mathrm{Na}_{2} \mathrm{~B}_{4} \mathrm{O}_{7} \cdot 4 \mathrm{H}_{2} \mathrm{O}\right)$ and tincalconite $\left(\mathrm{Na}_{2} \mathrm{~B}_{4} \mathrm{O}_{7} \cdot 5 \mathrm{H}_{2} \mathrm{O}\right)$. Recently, José Ma. Font Tullot ${ }^{4) 9}$ ) proposed its crystal structure on the basis of his X-ray data.

\section{Experimental}

As the material for this study, commercial borax was used after recrystallization. The lattice constants were determined first with the rotation photographs about the a-, b-and c-axes. The values obtained are $a_{0}=11.80 \pm 0.04 \AA, b_{0}=10.67 \pm 0.05 \AA, c_{0}=12.29 \pm 0.04 \AA$ and $\beta=106^{\circ} 35^{\prime}$ (from goniometer measurement). At the later stage of the analysis, the redetermination of these values was carried out by the powder method with a "Norelco" X-ray diffractometer, quartz and silicon being chosen as the standard substances. The results obtained are $a_{0}=11.858 \pm 0.005 \AA, b_{0}=10.674 \pm 0.005 \AA, c_{0}=12.197 \pm 0.005 \AA$ and $\beta=106^{\circ} 41^{\prime} \pm 2^{\prime}$. In the unit cell, there are four chemical units of composition $\mathrm{Na}_{2} \mathrm{~B}_{4} \mathrm{O}_{7} \cdot 10 \mathrm{H}_{2} \mathrm{O}$. The space group is $\mathrm{C}_{2 \mathrm{~h}}^{6}-\mathrm{C}^{2} / \mathrm{c}$, (hkl) being present only when $h+k=2 n,(h 0 l)$ only when $h=2 n$ and $l=$ $2 n$ and $(0 k 0)$ only when $k=2 n$. These results are in good agreement with the ones previously described ${ }^{8) 4}$.

Integrating Weissenberg photographs ${ }^{10)}$ were taken about the a-, b- and c-axes each up to the seventh layer by the multiple film technique. The samples used for this purpose were needle-crystals of about $0.5 \mathrm{~mm} . \times 0.5 \mathrm{~mm}$. in cross section and $1 \mathrm{~mm}$. in length. 
Throughout the experiments, $\operatorname{Cu} k \alpha$ radiation $(\lambda=1.542 \AA$ ) was used.

The relative intensities were estimated visually and corrected for the Lorentz and polarization factors. No correction was made for absorption, nor for extinction. After the relative intensities were adjusted to the same scale, they were put on to the absolute ones by Willson's method ${ }^{11)}$, which gave $B=1.40 \AA^{2}$ for the temperature factor parameter. At the later stage of the analysis, these absolute intensities were found to be less by about $5 \%$ than the values expected from the correct structure.

\section{Analysis}

Since no structure of hydrated sodium borates has so far been determined, it was impossible to assume beforehand the probable arrangement of atoms for this mineral from the structural view-point, and the usual trial and error method could not be effectively employed. Moreover, since this mineral has a number of comparatively light atoms such as sodium, oxygen, boron and hydrogen atoms in the large unit cell, the application of the Patterson function was not expected to be effective. Therefore, the only probable way of attacking the problem was to make use of the sign relationships of structure factors.

This method was first applied to the two-dimensional reflections, that is, $F_{h k 0}$ 's, $F_{k 0 l}$ 's and $F_{0 h l}$ 's. It was, however, impossible to obtain signs of reflections enough to produce a comprehensible Fourier projection.

Then all the three-dimensional observed structure factors, $F_{h k l}$ 's which amount to about 1800 including 681 absent ones, were used for the sign determination. Since the origin of the unit cell may be shifted from one symmetry centre to another, it is possible to choose the signs of two structure factors at will in the space group of borax, $\mathrm{C}_{2 h}^{6}$. Thus the positive sign was chosen for the reflections (170) and (735). It was found then that the signs of fifteen additional structure factors were uniquely determined from the following rela- 
tion by Harker and Kasper ${ }^{5)}$,

$$
\left(U_{h, k, l} \pm U_{\left.h^{\prime}, k^{\prime}, l^{\prime},\right)^{2}} \leq\left(1 \pm U_{h+h^{\prime}, k+k^{\prime}, l+l^{\prime}}\right)\left(1 \pm U_{h-h^{\prime}, k-k^{\prime}, l-l^{\prime}}\right)\right.
$$

On the basis of the known signs, Cochran's relation ${ }^{23)}, S_{\mathrm{H}}=S_{\mathrm{K}} \cdot S_{\mathrm{H}+\mathrm{K}}$, was applied to all the structure factors whose $U$-values were more than 0.30. According to this procedure, the signs of 66 structure factors were expressed by,+- and two letter symbols $a$ and $b$. For all the large structure factors not determined by the above methods and ones whose $U$-values were more than 0.20 , Zachariasen's relationship12), $S_{\mathrm{H}}=\left(\overline{S_{\mathrm{K}} \cdot S_{\mathrm{H}+\mathrm{K}}}\right)$, was tested, and the signs of additional 144 reflections, as well as of the letters a and $b$, were deduced from the known ones.

Up to this stage, therefore, the signs of comparatively large 225 structure factors had been collected and it was expected that a three-dimensional Fourier synthesis based on these factors would give a good approximation to the correct structure. The three-dimensional

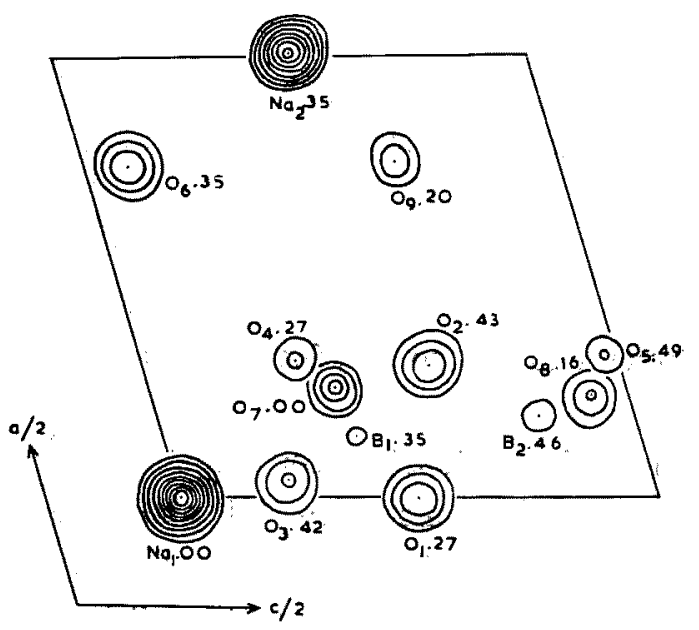

Fig. 1. The composite sections from $\rho(x y z)$ by the first triple Fourier series, The sections are projected on (010). The lower half only of $1 / 2 a_{0} \times 1 / 2 c_{0}$ is shown. Contours are drawn at equal intervals of an arbitray scale. The numbers give the height of each atom expressed as a percentage of the $b_{0}$-translation. 
Fourier summation was carried out over the points of $1 / 30 \times 1 / 30 \times$ $1 / 30$ of the unit cell. The Beever-Lipson strips were used for the calculation according to the next equation,

$$
\rho_{x_{y} z}=\frac{4}{V_{c}} \sum_{k=0}^{\infty}\left(J_{k x z} \cos 2 \pi k y-j_{k_{x} z} \sin 2 \pi k y\right),
$$

where $\quad J_{k x z}=\sum_{h} \sum_{l}^{l m 2 n}\left[F_{h k l} \cos 2 \pi(h x+l z)+F_{h k l} \cos 2 \pi(-h x+l z)\right]$ and $\quad j_{k x z}=\sum_{h} \sum_{l}^{l=2 n+1}\left[F_{h k l} \sin 2 \pi(h x+l z)+F_{h k l} \sin 2 \pi(-h x+l z)\right]$.

The composite Fourier sections from $\rho(x y z)$ are given in Fig. 1, projected on to (010).

Since the heights of peaks at the centres of sodium, oxygen and boron atoms in the three-dimensional electron density map were expected to have the proportion of about $3: 2: 1$ respectively as

Table 1. The atomic coordinates in borax.

\begin{tabular}{|c|c|c|c|c|c|c|c|c|c|c|}
\hline \multirow{2}{*}{ Atoms } & \multirow{2}{*}{$\begin{array}{l}\text { No. of atoms } \\
\text { in the cell }\end{array}$} & \multicolumn{3}{|c|}{ Column 1} & \multicolumn{3}{|c|}{ Column 2} & \multicolumn{3}{|c|}{ Column 3} \\
\hline & & $x / a_{0}$ & $y / b_{0}$ & $z / c_{0}$ & $x / a_{0}$ & $y / b_{0}$ & $z / c_{0}$ & $x / a_{0}$ & $y / b_{0}$ & $z / c_{0}$ \\
\hline $\mathrm{Na}_{1}$ & 4 & 0 & 0 & 0 & 0 & 0 & 0 & 0 & 0 & 0 \\
\hline $\mathrm{Na}_{2}$ & 4 & 0 & .847 & .250 & 0 & .843 & .250 & 0 & .845 & .250 \\
\hline $\mathrm{B}_{1}$ & 8 & .080 & .347 & .213 & .082 & .347 & .215 & .085 & .345 & .217 \\
\hline $\mathrm{B}_{2}$ & 8 & .095 & .460 & .390 & .098 & .450 & .397 & .095 & .454 & .390 \\
\hline $\mathrm{O}_{1}$ & 4 & 0 & .273 & .250 & 0 & .264 & .250 & 0 & .265 & .250 \\
\hline $\mathrm{O}_{2}$ & 8 & .143 & .427 & .305 & .156 & .420 & .318 & .154 & .419 & .314 \\
\hline $\mathrm{O}_{3}$ & 8 & .025 & .430 & .125 & .021 & .437 & .123 & .018 & .435 & .123 \\
\hline $\mathrm{O}_{4}$ & 8 & .158 & .267 & .170 & $.158^{*}$ & .264 & .167 & .161 & .269 & .167 \\
\hline $\mathrm{O}_{5}$ & 8 & .162 & .493 & .495 & .165 & $.493^{*}$ & $.495^{*}$ & .163 & .511 & .491 \\
\hline $\mathrm{O}_{6}$ & 8 & .127 & .850 & .447 & .123 & .845 & .453 & .123 & .846 & .450 \\
\hline $\mathrm{O}_{7}$ & 8 & .127 & 0 & .195 & .121 & .002 & .192 & .125 & .002 & .196 \\
\hline $\mathrm{O}_{8}$ & 8 & .117 & .157 & .462 & .120 & .163 & .455 & .119 & .165 & .459 \\
\hline $\mathrm{O}_{9}$ & 8 & .118 & .700 & .167 & $.118 *$ & .705 & .178 & .116 & .707 & .171 \\
\hline
\end{tabular}

Column 1: The coordinates from the first tripla Fourier series.

Column 2: The coordinates after $t$ wo-dimensional refinements.

Column 3: The final coordinates from the second triple Fourier saries. 
observed in other crystals, it was easy to allot two sodium, nine oxygen and two boron atoms to the appropriate peaks in the diagram of the unsymmetrical domain of the unit cell. The results thus derived produced a structure which showed no contradiction to the known crystallographic knowledge such as the ionic radii of atoms and the coordination number of cations. These first approximate coordinates of atoms are given in Table 1, column 1.

\section{Refinement of coordinates}

Two-dimensional Fourier methods were employed as far as possible to refine the atomic parameters. All the signs of observed $F_{h k 0}$ 's, $F_{h l}$ 's and $F_{0 k l}$ 's were derived from the above coordinates. Hartree's atomic scattering factors were used in this calculation with $B=$ $1.40 \AA^{2}$ for the temperature factor parameter. Two-dimensional Fourier diagrams projected on to (001), (010) and (100) were produced, the a-, b- and c-axes being divided into 60 parts. After several successive adjustments, all the signs ceased to change. The final coordinates of atoms whose peaks were resolved in the maps were given in Table 1, column 2. Throughout these processes, the original coordinates were used for oxygen atoms whose peaks overlapped in the maps and given in Table 1, column 2 with stars. The coordinates of boron atoms were adjusted in accordance with spatial requirements with oxygen atoms. The reliability factors based on these coordinates were 0.221 for $F_{h k 0}$ 's, 0.194 for $F_{h 0 l}$ 's and 0.253 for $F_{0 k l}$ 's, all present and absent reflections being counted.

The structure factors of general refections, $F_{h k l}$ 's, were then calculated with these coordinates. After calculation, it was found that the originally observed $F$-values should be increased by $5 \%$ to obtain the least values for the reliability factors, which reduced from 0.240 to 0.231 including present and absent reflections. With the corrected values of observed $F_{h k l}$ 's, the three-dimensional Fourier series were recalculated, each axis being divided into 30 parts as earlier. The composite Fourier sections from $\rho(x y z)$ are projected on (010) and 


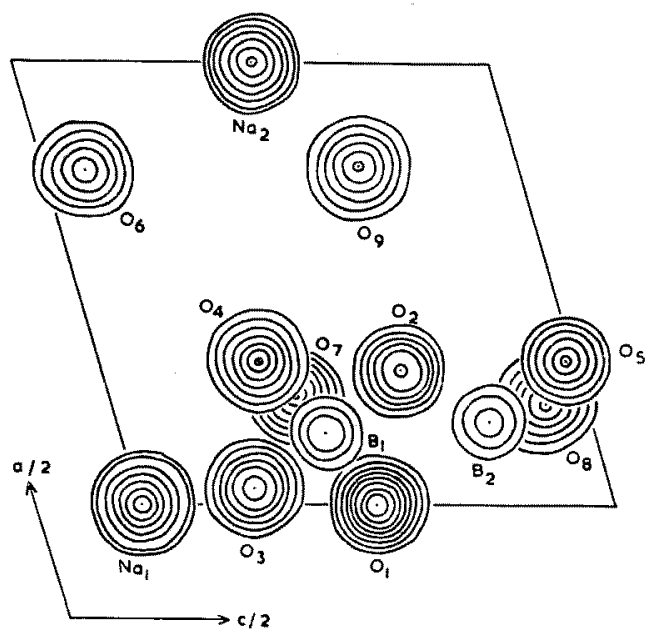

(a)

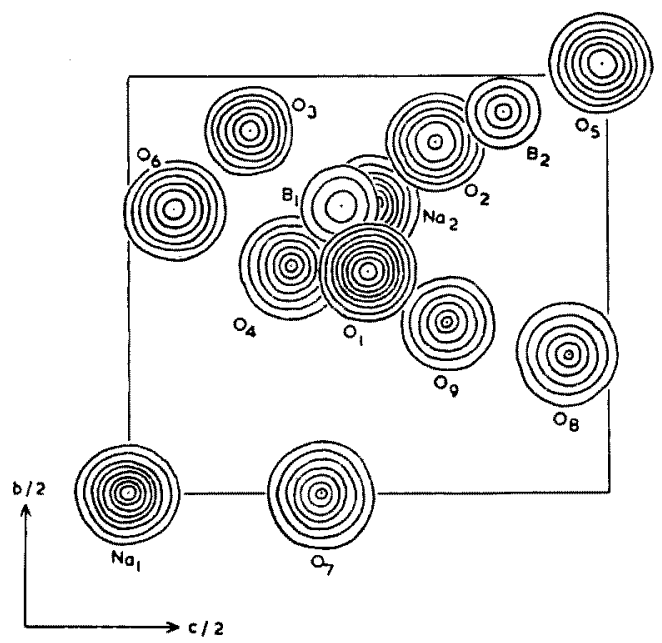

(b)

Fig. 2. The composite sections from $\rho(x y z)$ by the second triple Fourier series. The sections are projected on (a) (010) and (b) (100). The lower halves only of $1 / 2 a_{0} \times 1 / 2 c_{0}$ and $1 / 2 c_{0} \times 1 / 2 b_{0}$ are shown in (a) and (b) respectively. Dots indicate positions of atoms according to the final parameters. Contours are drawn at $2,4,6 \ldots \ldots e . \AA^{-3}$ for boron and oxygen atoms and $2,4,8,12, \ldots . . e$. $\AA^{-3}$ for sodium atoms. 
(100) in Fig. 2. The position of each peak in the diagram was determined by Megaw's method?), and was given in Table 1, column 3. As for hydrogen atoms, the positions were not determined in the diagram, though some swellings of electron density were observed at the places where hydrogen atoms would be expected as mentioned below.

In order to refine the temperature factor parameter, at this stage, the profiles through the peaks of sodium, oxygen and boron atoms were plotted by averaging the observed $\rho$-values of atoms of the same kind in the electron density map and compared with those calculated from Hartree's atomic scattering factors modified with the temperature factor parameter, $B=1.40 \AA^{2}$. This indicated that the temperature factor parameter thereto adopted should be increased to $B=1.60 \AA^{2}$. The structure factors of $F_{h k l}$ 's were calculated again on the basis of the new coordinates and the revised temperature factor.

Only the calculated values of $F_{h k 0}$ 's, $F_{h 0 l}$ 's and $F_{h 0 l}$ 's are compared with the observed values in Table 2 , the reliability factors of which are $0.190,0.154$, and 0.212 respectively. The reliability factor for all observed (present and absent) reflections is 0.220 . In view of the facts that there are many absent reflections (not including spacegroup extinctions) which amount to $38 \%$ of all observed ones and that the hydrogen atoms were neglected in the calculation of the structure factors, this value of reliability factor seems to be sufficient to establish the structure under consideration.

\section{Accuracy}

In this work, systematic errors such as from extinction, absorption and termination effect in Fourier synthesis were not corrected. Therefore, in order to take accunt of these errors, the order of magniude of the standard deviation of atomic coordinates was estimated from the following expression, 
Table 2. Comparison of observed and calculated $F$-values.

Only $F_{h k 0}$ 's, $F_{h o l}$ 's and $F_{0 k l}$ 's are given.

\begin{tabular}{|c|c|c|c|c|c|c|c|c|}
\hline$h k l$ & Fobs. & Fcalc. & $h k l$ & Fobs. & Fcalc. & $h k l$ & Fobs. & Fcalc. \\
\hline 020 & 33 & 34 & 6.10 .0 & 12 & 18 & 10.0 .0 & 38 & 35 \\
\hline 040 & 83 & 88 & 6.12 .0 & 19 & 23 & 12.0 .0 & 28 & 26 \\
\hline 060 & 80 & 83 & & & & 14.0 .0 & 6 & 8 \\
\hline 080 & 12 & 16 & 710 & 11 & 22 & & & \\
\hline 0.10 .0 & 12 & 21 & 730 & 22 & -19 & 002 & 37 & -34 \\
\hline 0.12 .0 & 38 & 50 & 750 & 30 & 31 & 202 & 54 & -53 \\
\hline & & & & 82 & 79 & 402 & 38 & \\
\hline 110 & 23 & -15 & 790 & 15 & -26 & 602 & 27 & -25 \\
\hline 130 & 24 & -31 & 7.11 .0 & 8 & 7 & 802 & 22 & -22 \\
\hline 150 & 38 & 39 & & & & 10.0.2 & 15 & -14 \\
\hline 170 & 133 & 142 & 800 & 134 & 128 & 12.0 .2 & 24 & -21 \\
\hline 190 & - & -3 & 820 & - & 0 & & & \\
\hline 1.11 .0 & 31 & 29 & 840 & 12 & 8 & 004 & 90 & 90 \\
\hline 1. 13.0 & 11 & 11 & 860 & 38 & 44 & 204 & 163 & 211 \\
\hline & & & 880 & - & 4 & 404 & 26 & 33 \\
\hline 200 & 94 & 118 & 8.10 .0 & 6 & - & 604 & 31 & -30 \\
\hline 220 & 19 & 16 & & & & 804 & 11 & 7 \\
\hline 240 & 6 & -6 & 910 & 64 & 61 & 10.0 .4 & 44 & 44 \\
\hline 260 & 27 & 27 & 930 & - & 3 & 12.0 .4 & 37 & 30 \\
\hline 280 & - & -4 & 950 & 26 & 29 & & & \\
\hline 2.10 .0 & 20 & -20 & 970 & 50 & 53 & 006 & 98 & 92 \\
\hline 2.12 .0 & 10 & 7 & 990 & 9 & 8 & 206 & 21 & $\begin{array}{l}-14 \\
-83\end{array}$ \\
\hline 310 & 41 & 48 & 10.0 .0 & 38 & 35 & 606 & 42 & 30 \\
\hline 330 & 32 & 30 & 10.2 .0 & - & 3 & 806 & 43 & 32 \\
\hline 350 & 36 & 42 & 10.4 .0 & - & -3 & 10.0 .6 & 14 & -6 \\
\hline 370 & - & -2 & 10.6 .0 & 30 & 29 & 12.0 .6 & - & 2 \\
\hline 390 & 31 & 29 & 10.8 .0 & 8 & -4 & & & \\
\hline 3.11 .0 & - & 6 & 10.10 .0 & - & -17 & 008 & $\overline{a r}$ & 3 \\
\hline 3. 13.0 & - & 14 & & & & 208 & 87 & 86 \\
\hline & & & 11.1 .0 & 12 & -12 & 408 & 96 & 106 \\
\hline 400 & 143 & -157 & 11.3 .0 & 6 & 2 & 608 & 24 & 22 \\
\hline 420 & 27 & & 11.5 .0 & 11 & & 808 & - & -5 \\
\hline 440 & 8 & -9 & 11. 7.0 & - & - & 10.0 .8 & 27 & 32 \\
\hline 460 & 43 & -42 & 11.9 .9 & 一 & 9 & & & \\
\hline 480 & 10 & 4 & & & & 0.0 .10 & - & 6 \\
\hline 4.10 .0 & - & -7 & 12.0 .0 & 28 & 26 & 2.0 .10 & 19 & 18 \\
\hline 4.12 .0 & 一 & -5 & 12.2 .0 & - & 12 & 4. 0.10 & 25 & -14 \\
\hline & & & 12.4 .0 & 14 & 15 & 6.0 .10 & 29 & -18 \\
\hline 510 & 26 & -27 & 12.6 .0 & 12 & -12 & 8.0 .10 & 18 & -16 \\
\hline 530 & - & -9 & 12.8 .0 & - & 11 & & & \\
\hline 550 & 10 & 13 & & & & 0.0 .12 & 12 & 10 \\
\hline 570 & 17 & 9 & 13.1 .0 & 22 & -21 & & & \\
\hline 590 & - & 1 & 13.3 .0 & 6 & 4 & 2.0.12 & 12 & 10 \\
\hline 5.11 .0 & 8 & -6 & 13.5 .0 & - & 1 & 4.0.12 & 6 & 17 \\
\hline & & & 14.0 .0 & 6 & 8 & 6.0 .12 & 45 & 37 \\
\hline 600 & 134 & 154 & & & & 0.0 .14 & 26 & -27 \\
\hline 620 & 39 & 22 & 200 & 94 & 118 & 2.0 .14 & - & -14 \\
\hline 640 & 53 & 60 & 400 & 143 & -157 & & & \\
\hline 660 & 19 & -11 & 600 & 134 & 154 & $20 \overline{2}$ & 10 & -6 \\
\hline 680 & 26 & 22 & 800 & 134 & 128 & $\begin{array}{l}40 \overline{2} \\
60 \overline{2}\end{array}$ & $\begin{array}{l}10 \\
16\end{array}$ & $\begin{array}{r}-6 \\
-\quad 8\end{array}$ \\
\hline
\end{tabular}




\begin{tabular}{|c|c|c|c|c|c|c|c|c|}
\hline $\begin{array}{c}80 \overline{2} \\
10.0 . \overline{2} \\
12.0 . \overline{2} \\
14.0 . \overline{2}\end{array}$ & $\begin{array}{l}19 \\
13 \\
- \\
\end{array}$ & $\begin{array}{r}15 \\
10 \\
-\quad 5 \\
-\quad 9\end{array}$ & $\begin{array}{c}061 \\
081 \\
0.10 .1 \\
0.12 .1\end{array}$ & $\frac{-}{40}$ & $\begin{array}{r}0 \\
-\quad 11 \\
14 \\
38\end{array}$ & $\begin{array}{l}067 \\
087 \\
0.10 .7 \\
0.12 .7\end{array}$ & $\begin{array}{l}29 \\
30 \\
- \\
-\end{array}$ & $\begin{array}{r}28 \\
27 \\
-\quad 2 \\
-\quad 1\end{array}$ \\
\hline $\begin{array}{c}20 \overline{4} \\
40 \overline{4} \\
60 \overline{4} \\
80 \overline{4} \\
10.0 . \overline{4} \\
12.0 . \overline{4} \\
14.0 . \overline{4}\end{array}$ & $\begin{array}{r}156 \\
140 \\
74 \\
18 \\
\frac{18}{47}\end{array}$ & $\begin{array}{r}-158 \\
-\quad 4 \\
160 \\
69 \\
-\quad 16 \\
4 \\
42\end{array}$ & $\begin{array}{c}002 \\
022 \\
042 \\
062 \\
082 \\
0.10 .2 \\
0.12 .2\end{array}$ & $\begin{array}{l}37 \\
83 \\
12 \\
87 \\
- \\
-\end{array}$ & $\begin{array}{r}-34 \\
91 \\
-\quad 8 \\
76 \\
11 \\
10 \\
5\end{array}$ & $\begin{array}{c}008 \\
028 \\
048 \\
068 \\
088 \\
0.10 .8\end{array}$ & $\begin{array}{l}\overline{42} \\
28 \\
- \\
-\end{array}$ & $\begin{array}{r}3 \\
46 \\
24 \\
8 \\
7 \\
-\quad 10\end{array}$ \\
\hline $\begin{array}{c}20 \overline{6} \\
40 \overline{6} \\
60 \overline{\overline{6}} \\
80 \overline{6} \\
10.0 . \overline{6} \\
12.0 . \overline{6} \\
14.0 . \overline{6}\end{array}$ & $\begin{array}{l}98 \\
68 \\
62 \\
60 \\
73 \\
- \\
-\end{array}$ & $\begin{array}{r}-102 \\
-76 \\
-64 \\
-\quad 45 \\
-67 \\
-\quad 3\end{array}$ & $\begin{array}{c}003 \\
023 \\
043 \\
063 \\
083 \\
0.10 .3 \\
0.12 .3\end{array}$ & $\begin{array}{l}\overline{22} \\
62 \\
16 \\
- \\
=\end{array}$ & $\begin{array}{r}\overline{19} \\
-59 \\
-\quad 22 \\
-\quad 9 \\
-\quad 2\end{array}$ & $\begin{array}{l}029 \\
049 \\
069 \\
089 \\
0.10 .9 \\
0.0 .10\end{array}$ & $\begin{array}{l}\overline{\overline{2}} \\
\overline{-} \\
\overline{-}\end{array}$ & $\begin{array}{r}4 \\
13 \\
-\quad 2 \\
-\quad 2 \\
-\quad 7\end{array}$ \\
\hline $\begin{array}{c}20 \overline{8} \\
40 \overline{8} \\
60 \overline{8} \\
80 \overline{8} \\
10.0 . \overline{8} \\
12.0 . \overline{8} \\
14.0 . \overline{8}\end{array}$ & $\begin{array}{r}58 \\
134 \\
67 \\
10 \\
34 \\
47 \\
20\end{array}$ & $\begin{array}{r}58 \\
134 \\
70 \\
6 \\
30 \\
52 \\
23\end{array}$ & $\begin{array}{c}004 \\
024 \\
044 \\
064 \\
084 \\
0.10 .4 \\
0.12 .4\end{array}$ & $\begin{array}{r}90 \\
16 \\
14 \\
105 \\
62 \\
\frac{36}{36}\end{array}$ & $\begin{array}{r}90 \\
24 \\
14 \\
110 \\
58 \\
8 \\
37\end{array}$ & $\begin{array}{l}0.4 .10 \\
0.6 .10 \\
0.8 .10 \\
0.10 .10\end{array}$ & $\frac{42}{27}$ & $\begin{array}{r}-\overline{2} \\
-26\end{array}$ \\
\hline $\begin{array}{l}2.0 .10 \\
4.0 . \overline{10} \\
6.0 .10 \\
8.0 . \overline{10} \\
10.0 . \overline{10} \\
12.0 . \overline{10} \\
14.0 .10\end{array}$ & $\begin{array}{l}31 \\
10 \\
18 \\
-\end{array}$ & $\begin{array}{r}-46 \\
7 \\
33 \\
-13 \\
-12 \\
22 \\
13\end{array}$ & $\begin{array}{c}005 \\
025 \\
045 \\
065 \\
085 \\
0.10 .5 \\
0.12 .5\end{array}$ & $\begin{array}{r}-8 \\
70 \\
31 \\
15 \\
-\end{array}$ & $\begin{array}{r}-\overline{20} \\
58 \\
34 \\
-\quad 24 \\
-\quad 9 \\
6\end{array}$ & $\begin{array}{l}0.0 .12 \\
0.2 .12 \\
0.4 .12 \\
0.6 .12 \\
0.8 .12\end{array}$ & $\begin{array}{l}12 \\
12 \\
36 \\
22\end{array}$ & $\begin{array}{r}10 \\
-\quad 14 \\
36 \\
-\quad 8 \\
20\end{array}$ \\
\hline $\begin{array}{l}4.0 .1 \\
6.0 .1 \\
8.0 .1 \\
10.0\end{array}$ & $\begin{array}{l}10 \\
31 \\
49 \\
25\end{array}$ & $\begin{array}{r}6 \\
34 \\
41 \\
-\quad 6 \\
25\end{array}$ & $\begin{array}{l}006 \\
026 \\
046 \\
066 \\
086\end{array}$ & $\begin{array}{l}98 \\
47 \\
85 \\
18\end{array}$ & $\begin{array}{r}92 \\
46 \\
93 \\
1 \\
15\end{array}$ & $\begin{array}{l}0.0 .13 \\
0.2 .13 \\
0.4 .13 \\
0.6 .13\end{array}$ & $\begin{array}{l}- \\
-\end{array}$ & $\begin{array}{l}5 \\
5 \\
0\end{array}$ \\
\hline $\begin{array}{c}12.0 . \overline{12} \\
14.0 . \overline{12} \\
001\end{array}$ & $\frac{35}{-}$ & $\begin{array}{r}46 \\
-\quad 13 \\
\end{array}$ & $\begin{array}{c}0.10 .6 \\
0.12 .6 \\
007\end{array}$ & 드 & $\begin{array}{r}52 \\
9 \\
-\end{array}$ & & $\begin{array}{l}26 \\
18\end{array}$ & $\begin{array}{r}-27 \\
12\end{array}$ \\
\hline $\begin{array}{l}021 \\
041\end{array}$ & $\begin{array}{r}107 \\
48\end{array}$ & $\begin{array}{r}-128 \\
-48\end{array}$ & $\begin{array}{l}027 \\
047\end{array}$ & $\begin{array}{l}34 \\
19\end{array}$ & $\begin{array}{r}34 \\
-21\end{array}$ & 0.4 .14 & - & 10 \\
\hline
\end{tabular}

$$
\sigma(x)=-\sigma\left(\frac{\partial \rho}{\partial x}\right) /\left(\frac{\partial^{2} \rho}{\partial x^{2}}\right)_{\text {peak }}
$$

Cochran 1$)$ has shown that $\sigma(\partial \rho / \partial x)$ may be evaluated by determining the slope of the background resulting from the synthesis, and this has the advantage of taking account of all sources of error. In this 
expression, the dominator simplifies to $-2 p \rho_{\text {peak }}$, if the atom has a Gaussian distribution near the peak. Surveys of the background remote from any atom gave

$$
\sigma(\partial \rho / \partial x) \approx \sigma(\partial \rho / \partial y) \approx \sigma(\partial \rho / \partial z) \approx 1.5 e . \AA^{-4},
$$

and the value of $p$ for each atom was determined by comparison of $\rho=\rho_{0} \exp \left(-p r^{2}\right)$ with the $\rho$-values of the atom in the electron density map, giving 6.1 for sodium, 4.1 for oxygen and 6.0 for boron atoms. These values gave $0.004 \AA$ for sodium, $0.012 \AA$ for oxygen and $0.013 \AA$ for boron atoms as the standard deviation, $\sigma(x)$.

The standard deviation in three dimensions, $\sigma(r)$, was estimated from $\sigma(x)$ of each atom. No error is associated with $\mathrm{Na}_{1}$ occupying the special position $(0,0,0)$. For $\mathrm{Na}_{2}$ occupying the special position $(0, y, 1 / 2)$, however, the error for its $y$-parameter must be considered and it is $0.004 \AA$ same as $\sigma(x)$. The standard deviation $\sigma(r)$ for oxygen and boron atoms was estimated as $0.021 \AA$ and $0.022 \AA$ respectively.

\section{Location of hydrogen atoms}

As mentioned above, it was impossible to find the location of ten independent hydrogen atoms in the unit cell and to distinguish between $\mathrm{O}^{2-}, \mathrm{OH}^{-}$and $\mathrm{H}_{2} \mathrm{O}$ groups only by means of the electron density distribution.

Table 3. Electrostatic valencies at oxygen atoms in borax.

\begin{tabular}{|c|c|c|c|}
\hline Atoms & Neighbours & $\begin{array}{l}\text { Electrostatic } \\
\text { valencies }\end{array}$ & $\begin{array}{l}\text { Supposed role } \\
\text { in borax }\end{array}$ \\
\hline $\mathrm{O}_{1}$ & $\mathrm{~B}_{1}, \mathrm{~B}_{1}$ & 1.50 & $\mathrm{O}^{2-}$ \\
\hline $\mathrm{O}_{2}$ & $\mathrm{~B}_{1}, \mathrm{~B}_{2}$ & 1.75 & $\mathrm{O}^{2-}$ \\
\hline $\mathrm{O}_{3}$ & $\mathrm{~B}_{1}, \mathrm{~B}_{2}$ & 1.75 & $\mathrm{O}^{2-}$ \\
\hline $\mathrm{O}_{4}$ & $\mathrm{~B}_{1}$ & 0.75 & $\mathrm{OH}^{-}$ \\
\hline $\mathrm{O}_{5}$ & $\mathbf{B}_{2}$ & 1.00 & $\mathrm{OH}^{-}$ \\
\hline $\mathrm{O}_{6}$ & $\mathrm{Na}_{1}, \mathrm{Na}_{2}$ & 0.33 & $\mathrm{H}_{2} \mathrm{O}$ \\
\hline $\mathrm{O}_{7}$ & $\mathrm{Na}_{1}, \mathrm{Na}_{2}$ & 0.33 & $\mathrm{H}_{2} \mathrm{O}$ \\
\hline $\mathrm{O}_{8}$ & $\mathrm{Na}_{1}$ & 0.17 & $\mathrm{H}_{2} \mathrm{O}$ \\
\hline $\mathrm{O}_{9}$ & $\mathrm{Na}_{2}$ & 0.17 & $\mathrm{H}_{2} \mathrm{O}$ \\
\hline
\end{tabular}


The consideration of the electrostatic valencies at the oxygen atoms, however, obviously shows the difference of their parts in the structure, as shown in Table 3. These distribution of electrostatic valencies can best be represented by taking $\mathrm{O}_{1}, \mathrm{O}_{2}$ and $\mathrm{O}_{3}$ (in Table $1 \&$ Table 3 ) as $\mathrm{O}^{2-}, \mathrm{O}^{4}$ and $\mathrm{O}^{5}$ as $\mathrm{OH}^{-}$, and $\mathrm{O}^{6}, \mathrm{O}^{7}, \mathrm{O}^{8}$ and $\mathrm{O}^{9}$ as $\mathrm{H}_{2} \mathrm{O}$.

On the other hand, among the distances between oxygen atoms where they are not coordinated to the same cation, eleven give the short distances of less than $3.1 \AA$ and the rest all greater than $3.3 \AA$ which must be classed as van der Waals contacts. These short distances, given in Table 4, may be regarded to suggest the places where the ten hydrogen atoms form hydrogen bonds. From the

Table 4. The distances between oxygen atoms shorter than $3.6 \AA$ in borax, excluding those coordinated to the same cation. The distances considered to form hydrogen bonds are shown with stars.

\begin{tabular}{c|c}
\hline Oxygen-oxygen & Distance $(\AA)$ \\
\hline $\mathrm{O}_{3}-\mathrm{O}_{5}$ & $2.74^{*}$ \\
$\mathrm{O}_{1}-\mathrm{O}_{8}$ & $2.75^{*}$ \\
$\mathrm{O}_{2}-\mathrm{O}_{7}$ & $2.82^{*}$ \\
$\mathrm{O}_{4}-\mathrm{O}_{6}$ & $2.84^{*}$ \\
$\mathrm{O}_{4}-\mathrm{O}_{9}$ & $2.86^{*}$ \\
$\mathrm{O}_{5}-\mathrm{O}_{6}$ & $2.86^{*}$ \\
$\mathrm{O}_{4}-\mathrm{O}_{7}$ & $2.92^{*}$ \\
$\mathrm{O}_{8}-\mathrm{O}_{9}$ & $2.94^{*}$ \\
$\mathrm{O}_{5}-\mathrm{O}_{8}$ & $3.11^{*}$ \\
$\mathrm{O}_{3}-\mathrm{O}_{9}$ & $3.12^{*}$ \\
$\mathrm{O}_{4}-\mathrm{O}_{5}$ & 3.17 \\
$\mathrm{O}_{1}-\mathrm{O}_{7}$ & 3.32 \\
$\mathrm{O}_{2}-\mathrm{O}_{8}$ & 3.32 \\
$\mathrm{O}_{4}-\mathrm{O}_{6}$ & 3.36 \\
$\mathrm{O}_{2}-\mathrm{O}_{9}$ & 3.44 \\
$\mathrm{O}_{3}-\mathrm{O}_{8}$ & 3.44 \\
$\mathrm{O}_{2}-\mathrm{O}_{9}$ & 3.46 \\
$\mathrm{O}_{4}-\mathrm{O}_{7}$ & 3.54 \\
$\mathrm{O}_{6}-\mathrm{O}_{6}$ & 3.56 \\
\hline
\end{tabular}


consideration of the tetrahedral on triangular bonds around the oxygen atoms as often observed in many other structures, ten hydrogen atoms were distributed over ten positions out of eleven as given in Table 4. The tetrahedral and triangular arrangements of bonds around the oxygen atoms in borax are shown schematically in Fig. 3 , where the probable positions of hydrogen atoms are also drawn.

(o) $0^{2-}$
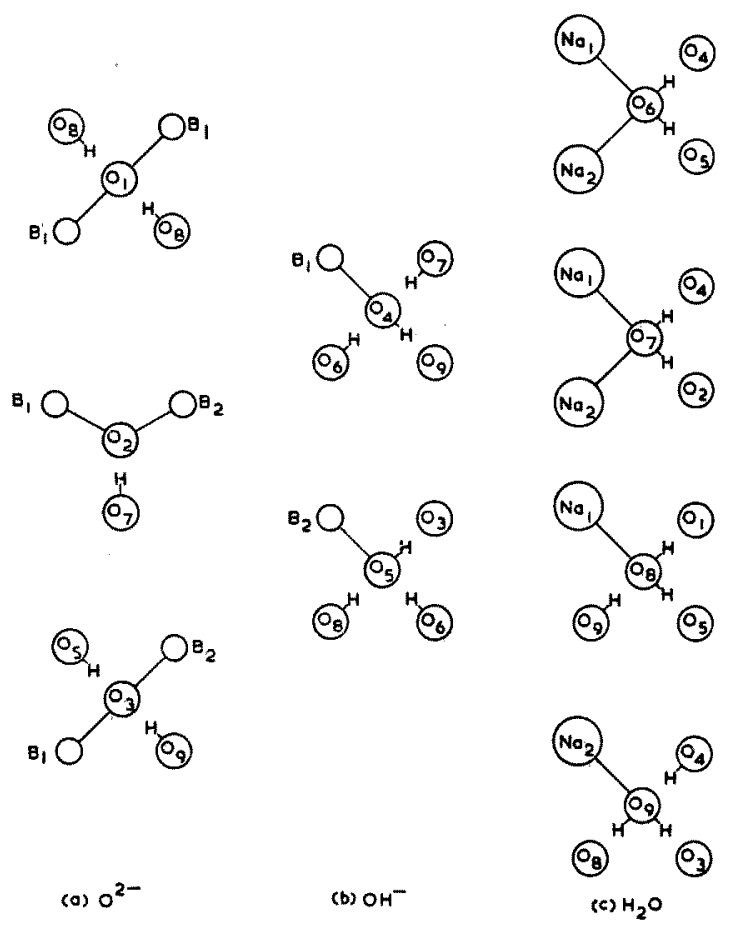

Fig. 3. The tetrahedral or triangular arrangement of bonds around the oxygen atoms in borax. The probable position of hydrogen atoms are drawn.

This result has certified the identification of atoms arrived at by the electrostatic valencies in the last paragraph.

\section{Description of the structure}

The structure of borax is projected on to (100), (010) and (001) in Fig. 4 (a), (b) and (c) respectively. In these figures, the atoms 
in only half of the unit cell are shown.

It is clear from the figures that the structure of borax consists of two constituent units, that is, the chains formed by sodium atoms and water molecules, and isolated groups formed by the rest of the constituent atoms. The chains have the composition of $\mathrm{Na}_{2} \cdot 8 \mathrm{H}_{2} \mathrm{O}$ and are built up with octahedra of water molecules around $\mathrm{Na}$, which

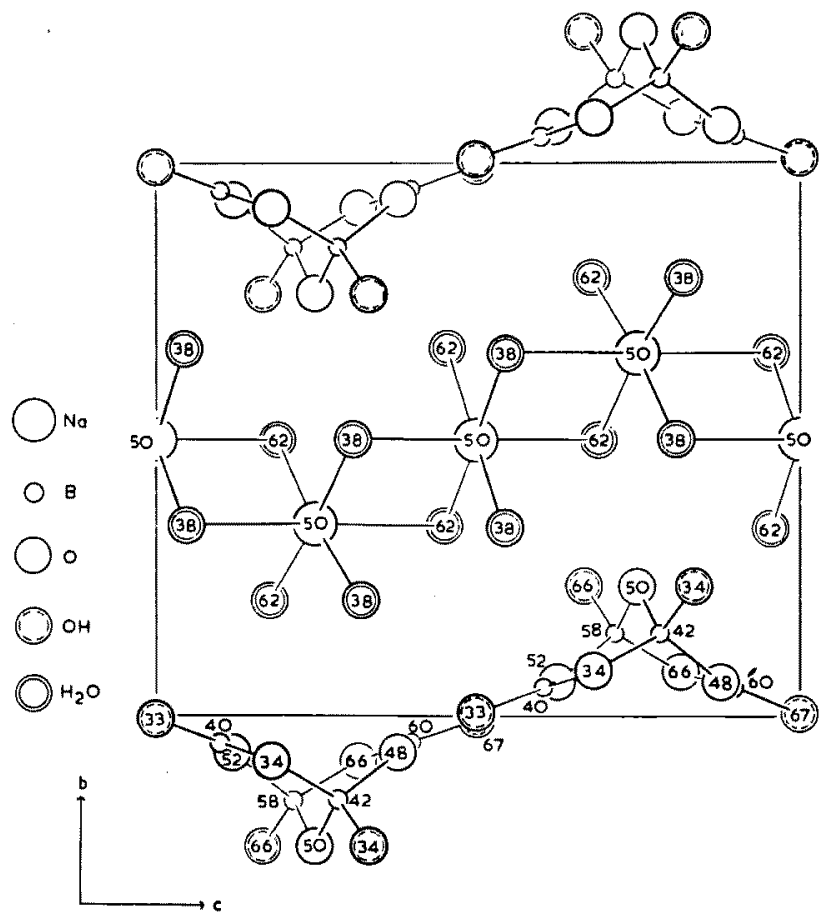

(a)

Fig. 4. The structure of borax. Numbers give the height of each atom in the cell expressed as a percentage of the $a_{0}-, b_{0}$ - or $c_{0}$-translation.

(a) Projection on (100). Only the atoms forming a single sheet are shown.

(b) Projection on (010). Only the middle half of the unit cell is shown. Broken lines represent the hydrogen bonds holding the isolated group $\mathrm{B}_{4} \mathrm{O}_{5}(\mathrm{OH})_{4}$ to each other.

(c) Projection on (001). Only the lower half of the unit cell is shown. 


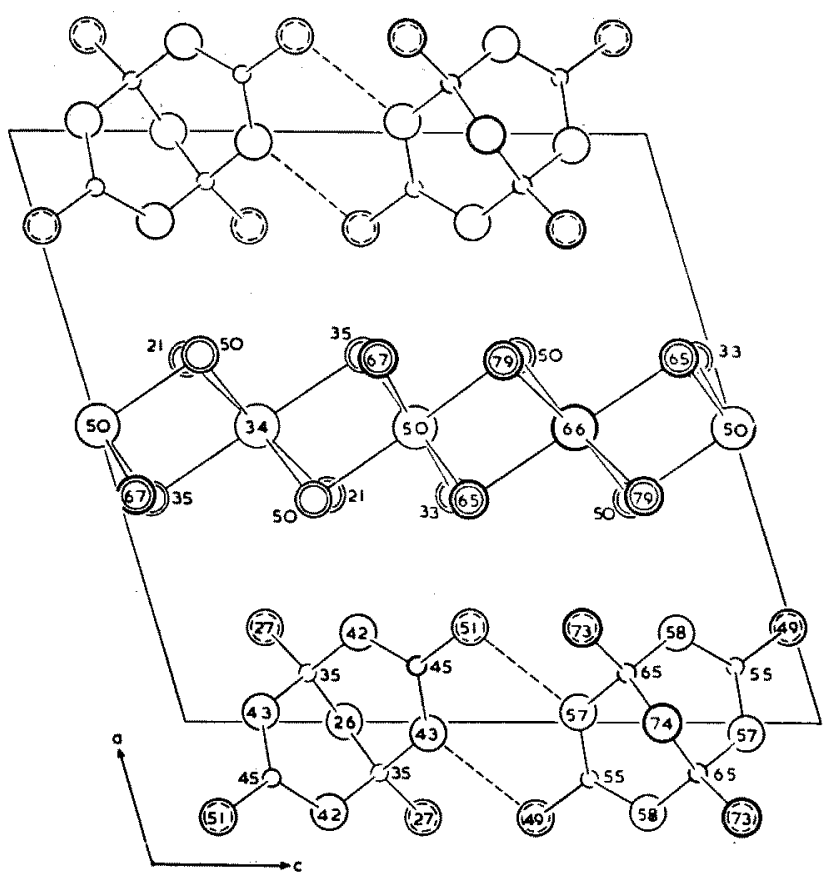

(b)

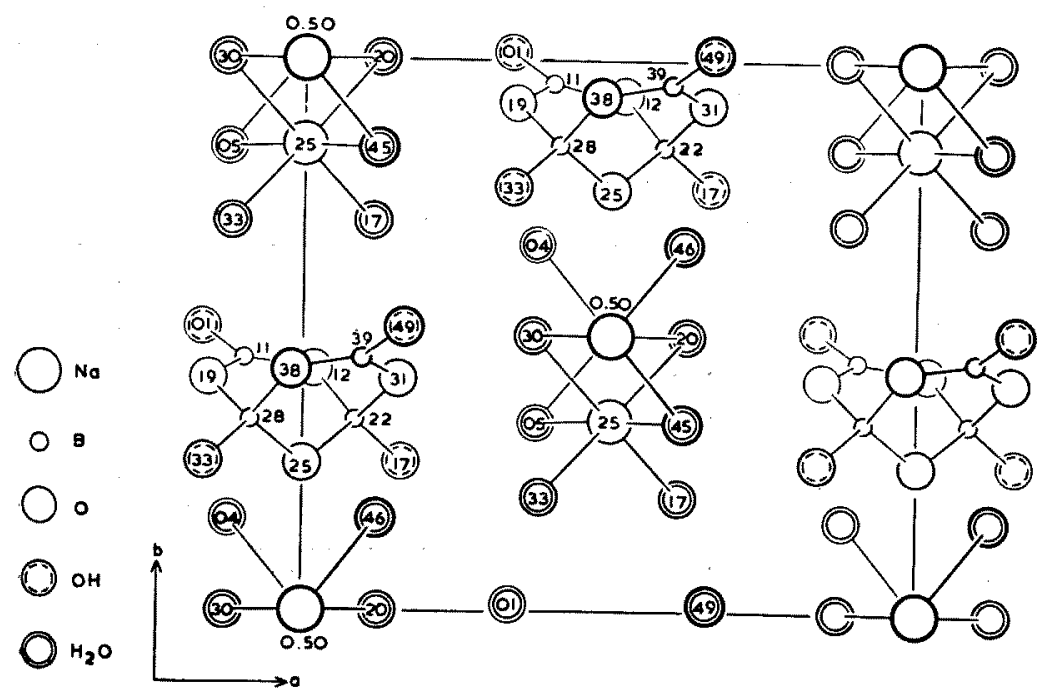

(c) 
link each other by holding the $\mathrm{H}_{2} \mathrm{O}-\mathrm{H}_{2} \mathrm{O}$ edges in common. These chains are stretched parallel to each other and to the c-axis. The isolated groups are composed of two tetrahedra formed by $\mathrm{O}^{2-}$ and $\mathrm{OH}^{-}$around $\mathrm{B}_{1}$ and two triangles formed by $\mathrm{O}^{2-}$ and $\mathrm{OH}^{-}$around $\mathrm{B}_{2}$ by sharing some of $\mathrm{O}^{2-}$ so as to make the composition of $\mathrm{B}_{4} \mathrm{O}_{5}$ $(\mathrm{OH})_{4}$.

The isolated groups are placed in between the chains to make a sheet parallel to $(100)$, the attraction between them being due to the hydrogen bonds. In this sheet, moreover, the isolated groups are connected with the neighbouring ones through the hydrogen bonds between $\mathrm{O}_{3}$ and $\mathrm{O}_{5}\left(\mathrm{O}_{3} \cdots \mathrm{H}-\mathrm{O}_{5}: 2.74 \AA\right)$, and make a chain parallel to the chains of water molecules around Na. This relation

Table 5. Interatomic distances in borax (in $\AA$ ).

1. Octahedron around $\mathrm{Na}_{1}$

$\begin{array}{ll}\mathrm{Na}_{1}-\mathrm{O}_{6} & 2.40 \\ \mathrm{Na}_{1}-\mathrm{O}_{7} & 2.44 \\ \mathrm{Na}_{1}-\mathrm{O}_{8} & 2.40 \\ \mathrm{O}_{6}-\mathrm{O}_{7} & 3.39,3.41 \\ \mathrm{O}_{6}-\mathrm{O}_{8} & 3.36,3.40 \\ \mathrm{O}_{7}-\mathrm{O}_{8} & 3.38,3.44\end{array}$

3. Tetrahedron around $B_{1}$

\begin{tabular}{ll}
\hline $\mathrm{B}_{1}-\mathrm{O}_{1}$ & 1.47 \\
$\mathrm{~B}_{1}-\mathrm{O}_{2}$ & 1.46 \\
$\mathrm{~B}_{1}-\mathrm{O}_{3}$ & 1.54 \\
$\mathrm{~B}_{1}-\mathrm{O}_{4}$ & 1.46 \\
$\mathrm{O}_{1}-\mathrm{O}_{2}$ & 2.42 \\
$\mathrm{O}_{1}-\mathrm{O}_{3}$ & 2.44 \\
$\mathrm{O}_{1}-\mathrm{O}_{4}$ & 2.40 \\
$\mathrm{O}_{2}-\mathrm{O}_{3}$ & 2.43 \\
$\mathrm{O}_{2}-\mathrm{O}_{4}$ & 2.42 \\
$\mathrm{O}_{3}-\mathrm{O}_{4}$ & 2.40 \\
\hline
\end{tabular}

2. Octahedron around $\mathrm{Na}_{2}$

\begin{tabular}{ll}
\hline $\mathrm{Na}_{2}-\mathrm{O}_{6}$ & 2.45 \\
$\mathrm{Na}_{2}-\mathrm{O}_{7}$ & 2.44 \\
$\mathrm{Na}_{2}-\mathrm{O}_{9}$ & 2.40 \\
$\mathrm{O}_{6}-\mathrm{O}_{7}$ & $3.39,3.50$ \\
$\mathrm{O}_{6}-\mathrm{O}_{1}$ & $3.17,3.68$ \\
$\mathrm{O}_{7}-\mathrm{O}_{9}$ & $3.16,3.16$ \\
\hline
\end{tabular}

4. Triangle around $B_{2}$

\begin{tabular}{ll}
\hline $\mathrm{B}_{2}-\mathrm{O}_{2}$ & 1.36 \\
$\mathrm{~B}_{2}-\mathrm{O}_{3}$ & 1.32 \\
$\mathrm{~B}_{2}-\mathrm{O}_{5}$ & 1.40 \\
$\mathrm{O}_{2}-\mathrm{O}_{3}$ & 2.38 \\
$\mathrm{O}_{2}-\mathrm{O}_{5}$ & 2.34 \\
$\mathrm{O}_{3}-\mathrm{O}_{5}$ & 2.34 \\
\hline
\end{tabular}


is clearly shown in Fig. 4 (b), in which the hydrogen bonds connecting the isolated groups are given specially. Therefore, this structure is best expressed by the formula $\mathrm{B}_{4} \mathrm{O}_{5}(\mathrm{OH})_{4} \cdot \mathrm{Na}_{2} 8 \mathrm{H}_{2} \mathrm{O}$. The perfect cleavage parallel to (100) may be explained from this structure, since (100) is the direction of the extention of sheets which are held together mainly by hydrogen bonds.

The interatomic distances in this structure are given in Table 5. It follows from the accuracy of this structure that $\mathrm{Na}-\mathrm{O}$ distances have a standard error of $0.02 \AA, \mathrm{B}-\mathrm{O}$ distances of $0.03 \AA$ and $\mathrm{O}-\mathrm{O}$ distances of $0.03 \AA$. The octahedron formed by water molecules around $\mathrm{Na}_{1}$ is a regular one within the limits of error, but those around $\mathrm{Na}_{2}$ is a little distorted. The mean values of interatomic distances $\mathrm{Na}-\mathrm{H}_{2} \mathrm{O}$ and $\mathrm{H}_{2} \mathrm{O}-\mathrm{H}_{2} \mathrm{O}$ are $2.42 \AA$, and $3.45 \AA$ respectively, in which the distance $\mathrm{Na}-\mathrm{H}_{2} \mathrm{O}$ is a little larger than the sum of the Goldschmidt radii, $2.30 \AA . \quad B_{1}$ is coordinated by four neighbours, one $\mathrm{OH}^{-}$and three $\mathrm{O}^{2-}$, arranged at the corners of a regular tetrahedron. The mean interatomic distances $\mathrm{B}-\mathrm{O}(\mathrm{OH})$ and $\mathrm{O}-\mathrm{O}$ (OH) are $1.48 \AA$ and $2.42 \AA$ respectively. These tetrahedra are found in datolite ${ }^{6)}$ with the interatomic distances $\mathrm{B}-\mathrm{O}(\mathrm{OH}) 1.49 \AA$ and $\mathrm{O}-\mathrm{O}(\mathrm{OH}) 2.43 \AA$. $\quad \mathrm{B}_{2}$ has three neighbours triangularly, one $\mathrm{OH}^{-}$ and two $\mathrm{O}^{2-}$. The mean values of $\mathrm{B}-\mathrm{O}(\mathrm{OH})$ and $\mathrm{O}-\mathrm{O}(\mathrm{OH})$ are $1.36 \AA$ and $2.35 \AA$ respectively, which are comparable with the triangle $\mathrm{B}(\mathrm{OH})_{3}$ in boric acid13), $1.36 \AA$ of $\mathrm{B}-\mathrm{OH}$ and $2.356 \AA$ of $\mathrm{OH}-\mathrm{OH}$.

\section{Acknowledgement}

The author wishes to express his sincere thanks to Prof. T. Ito, M. J. A. for his valuable suggestions and guidances during the course of this work, and to Dr. R. Sadanaga for his critical discussions and advice. He is also indebted to Mr. Y. Iitaka for his help in estimation of the lattice constants of borax with "Norelco" X-ray diffractometer and his valuable discussions. His thanks are also due to Prof. T. Watanabe, of the Geological Institute, University of Tokyo, and to Prof. N. Katayama and Dr. H. Minato, College 
of General Education, University of Tokyo, for their help and encouragements in this work.

\section{References}

1) Cochran, W.: Acta Cryst., 4, 81 (1951).

2) Cochran, W.: Acta Cryst., 5, 65 (1952).

3) Cochran, W. \& B. R. Penfold: Acta Cryst., 5, 644 (1952).

4) Font Tullot, José Ma.: Estud. Geol., 7, 13 (1947).

5) Harker, D., \& J.S. Kasper: Acta Cryst., 1, 70 (1948).

6) Ito, T. \& H. Mori : Acta Cryst., 6, 24 (1953).

7) Megaw, H. D.: Acta Cryst., 7, 771 (1954).

8) Minder, W.: Zeit. Krist., 92, 301 (1935).

9) Structure Reports for 1947-1948, 2, 431.

10) Wiebenga, E. H. \& D. W. Smits: Acta Cryst., 3, 265 (1950).

11) Willson, A. J. C.: Acta Cryst., 2, 318 (1949).

12) Zachariasen, W. H.: Acta Cryst., 5, 68 (1952).

13) Zachariasen, W. H.: Acta Cryst., 7, 305 (1954).

Manuscript received March 25, 1956. 